\title{
The Relationship Between Organizational Culture and Knowledge Management in Tequila Companies from Mexico
}

\author{
http://dx.doi.org/10.3991/ijac.v9i1.5748 \\ Marco Alberto Nuñez Ramírez, Teodoro Rafael Wendlandt Amezaga, and María Trinidad Álvarez Medina \\ Instituto Tecnológico de Sonora, Sonora, México
}

\begin{abstract}
The purpose of this research is to determine the degree of association between organizational culture and knowledge management. Using a quantitative and crosssectional design, the Pearson correlation coefficient was used to assess the relationship between variables, as well as a hierarchical multiple regression in order to measure the potential impact of organizational culture on knowledge management. To test some hypotheses, a sample of 39 tequila business organizations from the state of Jalisco was obtained, whose results provided empirical evidence that organizational culture can associate and explain to knowledge management.
\end{abstract}

Index Terms-organizational culture, knowledge management, tequila, Mexico.

\section{INTRODUCTION}

The era of knowledge has led to major changes at all levels, and so companies have had to adapt to new environments in order to become competitive [1]. This period is distinguished because it considers intangibles as the main assets of the organizations [2], among which it is possible to include the organizational culture [3] and knowledge management [4].

It should be noted that this research takes as theoretical baseline the Resource-Based View (RBV) proposed by Barney [5] and the Knowledge-Based View (KBV) developed by Grant [6]. According to the RBV, the intangible assets -as long as they are rare, valuable, inimitable and irreplaceable resources- can give the organization a sustained competitive advantage [5]. Therefore, the resources and intangible processes that belong to the company determine its competitiveness [7]; such is the case of the tacit and explicit knowledge.

For its part the KBV states that the main resource that companies have is knowledge. For Grant this theory is based on the transfer process, absorption capacity, appropriation, specialization and transformation of knowledge into products within the company [6]. This procedure is known as knowledge management [4].

It starts from the premise that culture is oriented toward the achievement of the objectives set by the organization [8]. Moreover, it is important to note that nowadays knowledge has become one of the main resources available to obtain a competitive advantage [9], being this the primary purpose of companies [10]. Therefore, from a strategic point of view, it is possible to affirm that both - organizational culture and knowledge management- are oriented towards a common end.

In the same way, the organizational culture (OC) is a key element in the construction and strengthening of the knowledge management (KM), determining how the members learn, acquire and share their knowledge [11]. For this reason the existing OC in the company is crucial for the KM [12], being considered as the main accelerator of the process of knowledge transfer [13].

It is possible to observe the relationship between these variables in some models of knowledge management, including the following: Nonaka and Takeuchi [4], Andersen [14], Tejedor and Aguirre [15], as well as Molina and Marsal [16]. For example, in Andersen the OC is related to the leadership and technology, which permit the learning within the organization; while for Tejedor and Aguirre the intervention of culture allows people, teams and the organization to integrate for the purpose of creating knowledge through the leadership and learning abilities.

Furthermore, some studies have found a certain relation between OC and KM [16-22]. However, although the empirical evidence supporting the aforementioned is scarce, this becomes even more evident within the context of Mexico, where cultural issues play an important role in the organizations [6].

There is no doubt that organizations need to shape the cultures that favors the KM, where members are encouraged to share knowledge that allows obtaining competitive advantages [11]. Nevertheless, it is still not clear how the organizational culture influences the knowledge management process. There are certain theoretical approaches that mention the existence of an explanatory level of OC on KM [11-13]; however, there is a lack of empirical evidence to support this approach, suggesting the need of corroboration.

Taking the foregoing into consideration, it's that the following research questions are proposed: How organizational culture is related to knowledge management? How organizational culture influences on knowledge management? To provide an answer to these questions the following hypotheses are presented:

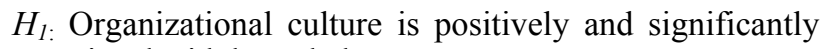
associated with knowledge management.

$\mathrm{H}_{2}$ : Organizational culture influences positively and significantly on knowledge management. 


\section{ORGANIZATIONAL CULTURE}

Since the late 1970 s culture has been considered as one of the elements that characterize organizations [23]. This includes the values, norms and symbols that guide the choices made by individuals and their interactions [24]. Among other aspects, it includes the human nature, time, its activities and relations [25]. Similarly, it could be considered as a collective mental programming [26] composed of meanings shared by its members, which differentiate an organization from another [27].

Such meanings were learned by a group as a solution to its problems of external adaptation and integration, which have worked efficiently to be considered valid and, therefore, be taught to new members as an appropriate way of perceiving, thinking, and feeling [28].

$\mathrm{OC}$ is an element of control and organizational evolution that acts as a driving force and development [29]. This force gives a sense of identity to employees and provides guidelines of understanding within the organization, which determines their existence by giving belonging and their own language [30].

They have emerged different approaches on this variable; however the perspective given by Cameron and Quinn [30] is one of those most widely known at present. Its diagnosis is based on the competing values framework (CVF) proposed by Quinn [31], which allows the identification of the best way to describe and manage the relationships, congruencies, and contradictions of the different aspects of the organization [32]. This posture divides the organizational culture in four distinct groups, these are: clan, adhocracy, hierarchy and market.

\section{A. Clan culture}

The clan culture is similar to a family-type organization. It implies values such as loyalty, personal commitment, teamwork, self-administration, tradition, extensive socialization and social influence [30]. In this culture the members recognize an obligation that goes beyond the simple exchange of work for a salary [33].

\section{B. Adhocracy culture}

In this culture there is a commitment to experimentation, innovation and being at the vanguard. The creation of change and effectiveness means offer new and exclusive products with a view to rapid growth. At the same time, it stimulates and rewards individual initiative, flexibility and the freedom driven towards the development of the organization [30].

\section{Market culture}

The market culture is characterized by achieving measurable and challenging goals, especially those that are financial and based on the market; prevailing strong competitiveness and orientation towards profit [30].

\section{Hierarchy culture}

This culture values formality, rules and operating procedures established as standards. Continued compliance with the duties and the exercise of the corresponding rights, is ensured by a system of rules and can only provide services to those who, according to general rules, are qualified to do so; the organization also operates in compliance with such standards [30].

\section{KNOWLEDGE MANAGEMENT}

The $\mathrm{KM}$ is the function that plans, coordinates and controls the flow of knowledge produced in the company in connection with their activities and their environment [1]. It is a process of creation, capture and use of knowledge to improve organizational performance [34].

For Nonaka, the knowledge is a dynamic human process that is divided into tacit and explicit [35]. The first is personal and difficult to formalize, which prevents its communication with the members of the organization [36], is based on actions and individual experience through mental models, beliefs and subjective perceptions that do not allow their explanation and articulation in manuals [37]. The second represents the rational part of knowledge, which can be expressed and easily explained in words and numbers, which can be transmitted to others to be processed collectively [38]. Within the KM approaches, the SECI model proposed by Nonaka and Takeuchi [4] is the one that has gained importance in recent years.

Nonaka and Takeuchi are based on the idea that the creation of organizational knowledge is the ability of a company -as a whole- to create knowledge, disseminate it throughout the organization and to characterize it in products, services and systems. More than knowledge creation they refer to the conversion of this one, i.e. convert it from tacit to explicit so it can be shared and used by the organization in order to create a new one [38].

This model argues that knowledge is initially created individually, which must be considered under two dimensions: epistemological and ontological [4]. In the first one two types of knowledge are recognized: tacit and explicit; while the ontological dimension goes from the individual to the group, team, organization, and even beyond. For this reason the generation emerges when the interaction between the tacit and explicit knowledge has an upward dynamic that goes from the lowest levels to the highest [35].

This model focuses on the origin of knowledge in itself and gives little importance to its relation to the environment or the contingency that surrounds it. In this way knowledge flows from tacit to tacit through empathizing; from tacit to explicit, by articulating; from explicit to explicit through connecting; and explicit to tacit by embodying [4].

It should be noted that knowledge needs a context to be created [39]. Each of the four modes of knowledge conversion is developed by a context or stage that permits the conversion of knowledge. These stages are socialization, externalization, combination, and internalization [4, Fig. 1]. That is why this model takes SECI by name, which is constituted by the initials of each stage; each of them is briefly described below.

\section{A. Socialization of knowledge}

Socialization creates synchronization and a basic understanding for the creation of knowledge, favoring a high autonomy of employees [4].

\section{B. Externalization of knowledge}

The externalization stimulates reflection through dialogue, on the basis of the formation of the individual knowledge and the group cohesion [4]. 


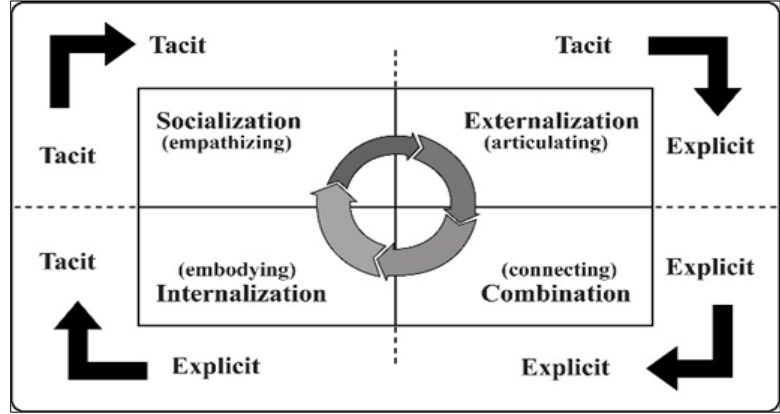

Figure 1. Knowledge management process [4]

\section{Combination of knowledge}

Combination it is supported by technological mediums that allow the mixture of different knowledge for the construction of archetypes [4].

\section{Internalization of knowledge}

The internalization seeks the creation of work environments that facilitate the assimilation of knowledge by members of the organization [4].

\section{METHOD}

\section{A. Research approach and design}

The present investigation utilizes a quantitative research approach as well as a nonexperimental research design. In consideration of the aims' perspective, the study is classified as a correlational and explanatory research. Quantitative research because a survey was used to test hypotheses, this by means of a numerical measurement and statistical analysis; correlational because it is intended to analyze the level of association among the variables; explanatory due to the nature of the linear regression; and nonexperimental because the variables were not manipulated [41].

\section{B. Data collection process and study sample}

During the period from January to June 2013, data were collected through the application of a survey as well as a questionnaire sent via email to tequila companies located in the state of Jalisco, Mexico. For the analyses and data processing, the statistical package for social sciences (SPSS, version 21) was utilized.

By means of a nonprobability sampling method, a convenience sample integrated of 39 tequila companies from the state of Jalisco was obtained. Some of the main characteristics of these companies are shown in Table I.

TABLE I.

CHARACTERISTICS OF THE STUDIED COMPANIES $(N=39)$

\begin{tabular}{lcc}
\hline \multicolumn{1}{c}{ Characteristics } & $\boldsymbol{n}$ & $\boldsymbol{\%}$ \\
\hline Size of the companies & & \\
$\quad$ Micro and small & 25 & 64.1 \\
Medium & 9 & 23.1 \\
Large & 5 & 12.8 \\
Market orientation & & \\
$\quad$ National & 10 & 25.6 \\
International & 6 & 15.4 \\
Both & 23 & 59 \\
Respondents position & & \\
$\quad$ Managers & 30 & 77 \\
$\quad$ Others & 9 & 23 \\
\hline
\end{tabular}

These companies were mostly located in areas of the state of Jalisco such as: Valles, Central, and Sur Altos.

\section{Measurement instrument}

The general measurement instrument of the study was composed of a socio-demographic section and two different instruments whose purpose was to measure the variables of organizational culture and knowledge management. For organizational culture the study used the Organizational Culture Assessment Instrument (OCAI) developed by Cameron and Quinn [30], which comprises 24 items; this instrument distinguishes between the four types of organizational culture aforementioned (clan, adhocracy, market and hierarchy). To measure knowledge management, it was used a questionnaire based on Mihi, García and Rojas [42] which was focused on the SECI model (socialization, externalization, combination, and internalization) of Nonaka and Takeuchi [4], including 11 items. All the questions (items) of the general instrument were answered using a Likert-type scale with five options to respond, ranging from 1 (Strongly disagree) to 5 (Strongly agree), where higher scores indicated higher levels of agreement.

Moreover, it is important to mention that a reliability assessment of the variables of the measurement instrument and its dimensions was performed by means of the Cronbach's alpha coefficient $(\alpha)$, where all coefficients resulted above the normal levels of acceptance $(\alpha \geq .70)$ [44]; this coefficient expresses the degree of measurement precision, accuracy, and predictability of the measuring instrument [45] (see Table II).

\section{RESUlTS}

Taking in consideration the study purposes, the Pearson product moment correlation coefficient $(r)$ was calculated in order to test the first hypothesis $\left(H_{l}\right)$. It is well known that this coefficient measures the linear association between variables, determining its magnitude and direction [41].

It was found that all components of $\mathrm{OC}$ and $\mathrm{KM}$ are associated positively and significantly $(p<.01)$. It should be noted that on average, the market culture obtained the highest coefficients of correlation with regard to the four different types of knowledge management (with socialization $[r=.74, p<.01]$, externalization $[r=.81, p<$ $.01]$, combination $[r=.73, p<.01]$, and internalization $[r$ $=.84, p<.01]$ ); followed by adhocracy and clan cultures.

With respect to the hierarchy culture the coefficients of correlation were the lowest, especially those associated-

TABLE II.

VARIABLES, DIMENSIONS AND RELIABILITY

\begin{tabular}{llcc}
\hline \multicolumn{1}{c}{ Variables } & Dimensions/factors & Elements & $(\alpha)$ \\
\hline \multirow{4}{*}{ Organizational } & Clan & 6 & .94 \\
Culture & Adhocracy & 6 & .89 \\
& Market & 6 & .89 \\
& Hierarchy & 6 & .90 \\
\hline \multirow{3}{*}{ Knowledge } & Socialization & 3 & .95 \\
Management & Externalization & 3 & .95 \\
& Combination & 3 & .94 \\
& Internalization & 2 & .77 \\
\hline \multirow{2}{*}{ Note. $\alpha=$ Cronbach's alpha coefficient. } & &
\end{tabular}


with socialization and externalization (same coefficient; $r$ $=.66, p<.01)$, followed by combination $(r=.58, p<.01)$, and internalization $(r=.77, p<.01)$; according to Hernández, Fernández-Collado and Baptista [41], this can be considered as moderate and acceptable (see Table III). These findings provide sufficient empirical evidence to support $H_{l}$.

To test the second hypothesis $\left(H_{2}\right)$, it was necessary to use a multiple regression analysis, which studies the relation between a dependent variable with two or more independent predictor variables [42].

The four types of OC (clan, adhocracy, market, and hierarchy) helped to explain significantly the variance in all KM variables, i.e. the socialization of knowledge $\left(R^{2}\right.$ $=.695, F=19.391, p<.001)$, the externalization $\left(R^{2}=.696\right.$, $F=19.469, p<.001)$, combination $\left(R^{2}=.777, F=29.561\right.$, $p<.001)$, and internalization $\left(R^{2}=.656, F=14.868, p<\right.$ $.001)$.

Moreover, the results showed that only three types of cultures influence the socialization of knowledge positively and significantly, these are: $\operatorname{clan}(\beta=0.761, p<$ $.001)$ market $(\beta=0.811, p<.05)$ and hierarchy $(\beta=0.10$, $p<.01)$. Taking as dependent variables the externalization and combination of knowledge respectively, it was found that both variables are influenced only by adhocracy $([\beta=$ $0.706, p<.05] ;[\beta=0.811, p<.01])$ and hierarchy $([\beta=$ $0.458, p<.05] ;[\beta=0.610, p<.001])$. The internalization of knowledge was exclusively influenced by the culture of hierarchy $(\beta=0.806, p<.001)$. It is noteworthy that hierarchy culture was the only one that showed significant influence on all the dimensions of knowledge management (see Table IV in next page). This empirical evidence supports to $\mathrm{H}_{2}$ partially.

TABLE III.

CORRELATION OF VARIABLES

\begin{tabular}{lccccccc}
\hline Dimension & $\mathbf{1}$ & $\mathbf{2}$ & $\mathbf{3}$ & $\mathbf{4}$ & $\mathbf{5}$ & $\mathbf{6}$ & $\mathbf{7}$ \\
\hline 1. Clan & - & & & & & & \\
2. Adhocracy & $.91^{* *}$ & - & & & & & \\
3. Market & $.92^{* *}$ & $.94^{* *}$ & - & & & & \\
4. Hierarchy & $.90^{* *}$ & $.84^{* *}$ & $.91^{* *}$ & - & & & \\
5. SO* & $.76^{* *}$ & $.75^{* *}$ & $.74^{* *}$ & $.66^{* *}$ & - & & \\
6. EX* & $.71^{* *}$ & $.76^{* *}$ & $.81^{* *}$ & $.66^{* *}$ & $.81^{* *}$ & - & \\
7. $\mathrm{CO}^{*}$ & $.60^{* *}$ & $.68^{* *}$ & $.73^{* *}$ & $.58^{* *}$ & $.78^{* *}$ & $.94^{* *}$ & - \\
8. IN* & $.75^{* *}$ & $.79^{* *}$ & $.84^{* *}$ & $.77^{* *}$ & $.85^{* *}$ & $.83^{* *}$ & $.81^{* *}$ \\
\hline Note. $* \mathrm{SO}=$ Socialization; $\mathrm{EX}=$ Externalization; $\mathrm{CO}=$ Combination; $\mathrm{IN}=$ Internalization. \\
${ }^{* *} p<.01, N=39$ (two-tailed).
\end{tabular}

TABLE IV.

MULTIPLE REGRESSION OF VARIABLES

\begin{tabular}{lcccc}
\hline \multirow{2}{*}{$\begin{array}{c}\text { Organizati } \\
\text {-onal } \\
\text { culture }\end{array}$} & \multicolumn{4}{c}{ Knowledge management $^{2}$} \\
\cline { 2 - 5 } & $\boldsymbol{S O}^{\mathbf{a}}$ & $\boldsymbol{E X}^{\mathbf{a}}$ & $\boldsymbol{C O}^{\mathbf{a}}$ & $\boldsymbol{I N}^{\mathbf{a}}$ \\
\hline Clan & $.761^{* * *}$ & .168. & -.061 & -.013 \\
Adhocracy & .362 & $.706^{*}$ & $.811^{* *}$ & .489 \\
Market & $.811^{*}$ & -.487 & -.480 & -.520 \\
Hierarchy & $.10^{* *}$ & $.458^{*}$ & $.610^{* * *}$ & $.806^{* * *}$ \\
$R^{2}$ & .695 & .696 & .777 & .656 \\
$R^{2}$-adjusted & .659 & .660 & .750 & .593 \\
$F$ & $19.39^{* * *}$ & $19.47^{* * *}$ & $29.56^{* * *}$ & $14.87^{* * *}$ \\
\hline
\end{tabular}

Note. ${ }^{\mathrm{a}} \mathrm{SO}=$ Socialization; $\mathrm{EX}=$ Externalization; $\mathrm{CO}=$ Combination; $\mathrm{IN}=$ Internalization $;{ }^{1} \mathrm{IV}=$ Independent variable; ${ }^{2} \mathrm{DV}=$ Dependent variable.

$* p<.05 . * * p<.01 . * * * p<.001$
In order to confirm the results found through multiple regression analysis, several hierarchical regressions were performed by introducing some control variables (sociodemographic variables as company size, location, and market orientation). It is important to note that the hierarchical regression analysis seeks to identify the main effects and interaction between the study variables [45], while the justification for the use of control variables is to avoid spurious relationships [46].

Trough the introduction of the control variables to the hierarchical regression model, a positive and significant effect on Socialization was obtained by OC (Table V).

TABLE V.

HIERARCHICAL REGRESSION ANALYSIS REGARDING SOCIALIZATION

\begin{tabular}{|c|c|c|c|c|}
\hline & & \multicolumn{3}{|c|}{ Socialization } \\
\hline Step & Predictor variable & $\beta$ & $\Delta \boldsymbol{R}^{2}$ & $\Delta F$ \\
\hline 1 & $\begin{array}{l}\text { Control variables } \\
\text { Company size } \\
\text { Location } \\
\text { Market orientation }\end{array}$ & $\begin{array}{r}.018 \\
-.025 \\
.084\end{array}$ & .213 & $3.166^{*}$ \\
\hline 2 & Clan culture & $.727 * * *$ & .373 & $30.609 * * *$ \\
\hline 1 & $\begin{array}{l}\text { Control variables } \\
\text { Company size } \\
\text { Location } \\
\text { Market orientation }\end{array}$ & $\begin{array}{r}.123 \\
-.061 \\
-.072\end{array}$ & .213 & $3.166^{*}$ \\
\hline 2 & Adhocracy culture & $.762 * * *$ & .363 & $29.114 * * *$ \\
\hline 1 & $\begin{array}{l}\text { Control variables } \\
\text { Company size } \\
\text { Location } \\
\text { Market orientation }\end{array}$ & $\begin{array}{r}.028 \\
.023 \\
-.034 \\
\end{array}$ & .213 & $3.166^{*}$ \\
\hline 2 & Market culture & $.736 * * *$ & .336 & $25.387^{* * *}$ \\
\hline 1 & $\begin{array}{l}\text { Control variables } \\
\text { Company size } \\
\text { Location } \\
\text { Market orientation }\end{array}$ & $\begin{array}{c}.20 \\
.121 \\
.095 \\
\end{array}$ & .213 & $3.166^{*}$ \\
\hline 2 & Hierarchy culture & $.585 * * *$ & .259 & $16.661 * * *$ \\
\hline
\end{tabular}

TABLE VI.

HIERARCHICAL REGRESSION ANALYSIS REGARDING EXTERNALIZATION

\begin{tabular}{|c|c|c|c|c|}
\hline \multirow[b]{2}{*}{ Step } & \multirow[b]{2}{*}{ Predictor variable } & \multicolumn{3}{|c|}{ Externalization } \\
\hline & & $\beta$ & $\Delta R^{2}$ & $\Delta F$ \\
\hline 1 & $\begin{array}{l}\text { Control variables } \\
\text { Company size } \\
\text { Location } \\
\text { Market orientation }\end{array}$ & $\begin{array}{r}.142 \\
.203 \\
.121 \\
\end{array}$ & .418 & $8.364 * * *$ \\
\hline 2 & Clan culture & $.511 * * *$ & .184 & $15.728 * * *$ \\
\hline 1 & $\begin{array}{l}\text { Control variables } \\
\text { Company size } \\
\text { Location } \\
\text { Market orientation }\end{array}$ & $\begin{array}{r}.215 \\
.157 \\
-.014 \\
\end{array}$ & .418 & $8.364 * * *$ \\
\hline 2 & Adhocracy culture & $.606^{* * *}$ & .229 & $29.114 * * *$ \\
\hline 1 & $\begin{array}{l}\text { Control variables } \\
\text { Company size } \\
\text { Location } \\
\text { Market orientation }\end{array}$ & $\begin{array}{r}.106 \\
.204 \\
-.016 \\
\end{array}$ & .418 & $8.364 * * *$ \\
\hline 2 & Market culture & $.688 * * *$ & .294 & $25.387 * * *$ \\
\hline 1 & $\begin{array}{l}\text { Control variables } \\
\text { Company size } \\
\text { Location } \\
\text { Market orientation }\end{array}$ & $\begin{array}{l}.121 \\
.300^{*} \\
.117\end{array}$ & .418 & $8.364 * * *$ \\
\hline 2 & Hierarchy culture & $.480 * * *$ & .174 & $14.518 * * *$ \\
\hline
\end{tabular}


Regarding externalization (Table VI), in the next table it is shown that the introduction of control variables improved the direct effect of the study variables with respect to the significance level. In this case, even the control variable named 'location' obtained a statistical significance $(\beta=.300, p<.05)$.

Furthermore, in the next table it can be seen a significant and positive effect on combination (see Table VII); again, the control variable named 'location' obtained statistical significance $(\beta=.297, p<.05)$.

TABLE VII.

HIERARCHICAL REGRESSION ANALYSIS REGARDING COMBINATION

\begin{tabular}{|c|c|c|c|c|}
\hline & & \multicolumn{3}{|c|}{ Combination } \\
\hline Step & Predictor variable & $\beta$ & $\Delta \boldsymbol{R}^{2}$ & $\Delta F$ \\
\hline 1 & $\begin{array}{l}\text { Control variables } \\
\text { Company size } \\
\text { Location } \\
\text { Market orientation }\end{array}$ & $\begin{array}{l}.089 \\
.229 \\
.208\end{array}$ & .391 & $7.478 * * *$ \\
\hline 2 & Clan culture & $.377 *$ & .100 & $6.685^{*}$ \\
\hline 1 & $\begin{array}{l}\text { Control variables } \\
\text { Company size } \\
\text { Location } \\
\text { Market orientation }\end{array}$ & $\begin{array}{l}.139 \\
.184 \\
.095 \\
\end{array}$ & .391 & $7.478 * * *$ \\
\hline 2 & Adhocracy culture & $.486 * *$ & .148 & $29.114 * *$ \\
\hline 1 & $\begin{array}{l}\text { Control variables } \\
\text { Company size } \\
\text { Location } \\
\text { Market orientation }\end{array}$ & $\begin{array}{l}.046 \\
.217 \\
.086\end{array}$ & .391 & $7.478 * * *$ \\
\hline 2 & Market culture & $.576 * * *$ & .206 & $17.377 * * *$ \\
\hline 1 & $\begin{array}{l}\text { Control variables } \\
\text { Company size } \\
\text { Location } \\
\text { Market orientation }\end{array}$ & $\begin{array}{l}.056 \\
.297 * \\
.407\end{array}$ & .391 & $7.478 * * *$ \\
\hline 2 & Hierarchy culture & $.407 * *$ & .125 & $8.778 * *$ \\
\hline
\end{tabular}

TABLE VIII.

HIERARCHICAL REGRESSION ANALYSIS REGARDING INTERNALIZATION

\begin{tabular}{|c|c|c|c|c|}
\hline \multirow[b]{2}{*}{ Step } & \multirow[b]{2}{*}{ Predictor variable } & \multicolumn{3}{|c|}{ Internalization } \\
\hline & & $\beta$ & $\Delta \boldsymbol{R}^{2}$ & $\Delta F$ \\
\hline 1 & $\begin{array}{l}\text { Control variables } \\
\text { Company size } \\
\text { Location } \\
\text { Market orientation }\end{array}$ & $\begin{array}{r}-.021 \\
-.017 \\
.077\end{array}$ & .191 & 2.756 \\
\hline 2 & Clan culture & $.742 * * *$ & .388 & $31.394 * * *$ \\
\hline 1 & $\begin{array}{l}\text { Control variables } \\
\text { Company size } \\
\text { Location } \\
\text { Market orientation }\end{array}$ & $\begin{array}{r}.088 \\
-.074 \\
-.107 \\
\end{array}$ & .191 & 2.756 \\
\hline 2 & Adhocracy culture & $.847 * * *$ & .448 & $42.220 * * *$ \\
\hline 1 & $\begin{array}{l}\text { Control variables } \\
\text { Company size } \\
\text { Location } \\
\text { Market orientation }\end{array}$ & $\begin{array}{r}-.054 \\
.000 \\
-.098 \\
\end{array}$ & .191 & 2.756 \\
\hline 2 & Market culture & $.924 * * *$ & .530 & $64.454 * * *$ \\
\hline 1 & $\begin{array}{l}\text { Control variables } \\
\text { Company size } \\
\text { Location } \\
\text { Market orientation }\end{array}$ & $\begin{array}{r}-.071 \\
.121 \\
.060\end{array}$ & .191 & 2.756 \\
\hline 2 & Hierarchy culture & $.757 * * *$ & .433 & $39.221 * * *$ \\
\hline
\end{tabular}

Finally, in the last table (Table VIII) it can be appreciated that all types of organizational culture significantly affect the internalization values.

In general terms, the results show that the values obtained by the hierarchical regression improved to those shown in multiple regression. This suggests that the types of organizational culture affect positively and significantly to knowledge management; thus, this information provides support to $\mathrm{H}_{2}$.

\section{CONCLUSIONS}

The objective of this research was to determine the degree of association between $\mathrm{OC}$ and $\mathrm{KM}$, and also to assess the level of influence of organizational culture on knowledge management.

The empirical evidence found in the sample of 39 tequila companies served to support the two hypotheses. OC was found to be positively and significantly associated with KM. The present results confirm the postures of Molina and Marsal [16], Lai [17], Jassawalla and Sashital [18], Glibsy and Holden [19], Lin and Lee [20], Palanisamy [21], Kamur [11] Ming-Fong and Gwo-Guang [12], and Wang, Su and Yang [22], according to which there is a positive relationship between the study variables. Similarly, it was observed that all cultures (clan, adhocracy, market, and hierarchy) were significantly associated with knowledge management.

Furthermore, through a multiple regression it was found that the OC influences positively and significantly on KM. Initially, through multiple regressions, results showed that hierarchy culture influences more on knowledge management; however, after conducting hierarchical regressions introducing some control variables, it was confirmed that the four cultures (clan, adhocracy, market, and hierarchy) affect positively to knowledge management.

The findings seem to agree with the comments of Kamur [11], and Glipsy and Holden [19], who claim that $\mathrm{OC}$ is a critical factor in building and strengthening KM, which in turn impacts how members learn, acquire and share knowledge. Also, it means that the company culture is crucial for the $\mathrm{KM}$ [12], being the main driver in the process of generation and transfer of knowledge [13].

This research sought to contribute to the study of organizational culture, seen as an intangible resource capable of giving a competitive advantage to companies [3], which has an association with a variable of great importance like it is the knowledge management.

Likewise, the study sought out to contribute with empirical evidence regarding the implementation of the $\mathrm{RBV}$ and $\mathrm{KBV}$, this if we consider that the study variables are valuable resources for companies within the current knowledge society. Thus, it should be understood that to achieve a successful knowledge management - which may be reflected in a competitive advantage-, it requires the participation of organizational culture seen as a strategic element.

The findings may be of great importance to increase the competitiveness of companies in the tequila industry. It should be noted that this industry in Mexico is characterized as an oligopoly in which three companies control $60 \%$ of the market. Its success can be attributed to 
the conception of knowledge management as a strategic resource to ensure leadership [47].

So it is necessary that the tequila companies perceive culture as a strategy to make the process of generation and transmission of knowledge more efficient, this through the conversion of socialization, externalization, combination, and internalization of tacit knowledge into explicit, and thus obtaining a competitive advantage consequently.

Based on the findings, it is recommended to extend this study in other cultural contexts, which can provide more empirical evidence to generalize the association between these variables. It would also be appropriate to evaluate what kind of culture is associated with -even explains in the best possible manner- the process of KM. This could favor the understanding of how certain cultures can be regarded as friendly or unfriendly with KM [13]. Furthermore, it would be convenient to involve -within the relationship of $\mathrm{OC}$ and $\mathrm{KM}$ - other variables that serve as intangible assets (such as innovation, technology, intellectual capital, human capital and organizational learning), and confirm their relation in a model by utilizing structural equation modeling.

The main limitation of this research was the sample size $(n=39)$, which is not representative of a total population of 152 companies [48]. Another limitation was the nonprobability sampling method used, thus it would be desirable to replicate this study with a more representative sample and using a probability sampling method in subsequent studies. Additionally, it is recommended to consider and assess these variables in other industries, as well as utilize a longitudinal study design to compare results.

The knowledge society demands to consider the relevance of intangible assets within organizations [1-3]. Although this posture is shown in the resource-based view [5] as well as the knowledge-based view [6], the relationship between intangible variables such OC and $\mathrm{KM}$ is a subject that -although it has drawn the theorists' attention [12, 13] - still requires further empirical evidence. The present study provides evidence that culture can associate and explain the $\mathrm{KM}$ by utilizing the taxonomy proposed by Cameron and Quinn.

\section{ACKNOWLEDGMENT}

The authors acknowledge the institutional support of the Instituto Tecnológico de Sonora trough the "Program for the Support and Development of Research Projects" (PROFAPI, by its Spanish acronym).

\section{REFERENCES}

[1] E. Bueno, "La Gestión del Conocimiento: Nuevos perfiles profesionales [The Knowledge Management: New professional profiles]," Boletín de Estudios Económicos, vol. 3, pp. 207-229, 1999.

[2] A. Brooking, El capital intelectual, el principal activo de las empresas del tercer milenio [The intellectual capital, the main asset of companies of the third Millennium]. Barcelona, España: Paidós, 1997.

[3] J. B. Barney, "Strategic Factor Markets: Expectations, Luck and Business Strategy," Management Science, vol. 32, pp. 1231- 1241, 1986. http://dx.doi.org/10.1287/mnsc.32.10.1231

[4] I. Nonaka and H. Takeuchi, The knowledge-creating company. New York: Oxford University Press, 1995.
[5] J. B. Barney, "Firm resources and sustained competitive advantage," Journal of Management, vol. 17, pp. 99-120, 1991. http://dx.doi.org/10.1177/014920639101700108

[6] R. M. Grant, "Toward a knowledge-based theory of the firm," Strategic Management Journal, vol. 17, pp. 109-122, winter 1996.

[7] N. Bontis, "Managing organizational knowledge by diagnosing intellectual capital: framing and advancing the state of the field," International Journal Technology Management, vol. 18, pp. 433462, 1999. http://dx.doi.org/10.1504/IJTM.1999.002780

[8] D. Denison, Organizational Culture: Can it be a key lever for driving organizational change? Lausanne, France: International Institute for Management, 2000.

[9] L. T. Lee and B. M. Sukoco, "The effects of entrepreneurial orientation and knowledge management capability on organizational and knowledge effectiveness in Taiwan: the moderating role of social capital," International Journal of Management, vol. 24, pp. 549-572, 2007.

[10] M. Porter, "How competitive forces shape strategy," Harvard Business Review, pp. 138-145, March-April 1979.

[11] R. Kamur, "Knowledge management and organizational culture: a theoretical integrative framework," Journal of Knowledge Management, vol. 15, pp. 779-801, 2011. http://dx.doi.org/10.1108/13673271111174320

[12] L. Ming-Fong and L. Gwon-Guang, "Relationships of organizational culture toward knowledge activities," Business Process Management, vol. 3, pp. 306-322, 2007.

[13] T. H. Davenport and L. Pusak, Working knowledge: How organizations manage what they know. Boston, United States: Harvard Business School, 1998.

[14] A. Andersen, El Management en el Siglo XXI [The Management in the XXI century]. Buenos Aires, Argentina: Editorial Granica, 1999.

[15] B. Tejedor and A. Aguirre, "Proyecto Logos: Investigación relativa a la capacidad de aprender de las empresas españolas [Logos Project: Investigation regarding the learning capacity in Spanish companies]," Boletín de Estudios Económicos, vol. 3, pp. 231-249, 1998.

[16] J. L. Molina and M. Marsal, La gestión del conocimiento en las organizaciones [The knowledge management in the organizations], 2002 [Online book: Businesses, Company, and Economy Collection]. Retrieved from http://www.librosenred.com/libros/lagestiondelconocimientoenlas organizaciones.html

[17] G. Lai, "A study of the correlation between corporate culture and knowledge-management type regarding the composition of corporate intellectual capital", Master dissertation, Taiwan, National Cheng-Chi University, 2002.

[18] A. R. Jassawalla and H. Sashittal, "Cultures that support productinnovation process," Academy of Management Executive, vol. 16, pp. 42-54, 2002. http://dx.doi.org/10.5465/AME.2002.8540307

[19] M. Glibsy and N. Holden, "Contextual constraints in knowledge management theory: the cultural embeddedness of Nonaka's knowledge-creating company," Knowledge and Process Management, vol. 10, pp. 29-36, 2003. http://dx.doi.org/10.1002/kpm.158

[20] H. Lin and G. Lee, "Perceptions of senior managers toward knowledge-sharing behavior," Management Decision, vol. 42, pp. 108-125, 2004. http://dx.doi.org/10.1108/00251740410510181

[21] R. Palanisamy, "Organizational culture and knowledge management in ERP implementation: an empirical study," Journal of Computer Information Systems, vol. 48, pp. 100-120, 2007.

[22] D. Wang, Z. Su and D. Yang, "Organizational culture and knowledge creation capability," Journal of Knowledge Management, vol. 15, pp. 363-373, 2011. http://dx.doi.org/10.1108/13673271111137385

[23] P. Podestá, "La cultura en las organizaciones: un fenómeno central en el saber administrativo [The culture in the organizations: a central phenomenon in the management knowledge]," Cuadernos de Difusión, vol. 14, pp. 82-92, 2009.

[24] T. Parsons and E. Shils, Toward a general theory of action. Cambridge: Harvard University Press, 1951. http://dx.doi.org/10.4159/harvard.9780674863507 
[25] F. Kuckhohn and F. Strodtbeck, Variations in value orientations. Westport: Greenwood Press, 1961.

[26] G. Hofstede, Culture's Consequences: International differences in Wold-Related Values. New York, United States: SAGE Publications, 1980.

[27] S. P. Robbins, Essentials of organizational behavior, $7^{\text {th }}$ ed. New Jersey, United States: Prentice Hall, 2002.

[28] E. Schein, Organizational culture and leadership. San Francisco, United States: Jossey-Bass Publications, 1992.

[29] M. Alvesson and P. Olof, Corporate Culture and Organizational Symbolism. An Overview. New York, United States: Walter de Gruyter Publications, 1992. http://dx.doi.org/10.1515/978311 $\underline{0136074}$

[30] K. Cameron and R. Quinn, Diagnosing and changing organizational culture, based on the competing values framework. San Francisco, United States: Jossey-Bass Publications, 2006.

[31] R. E. Quinn, Beyond rational management. San Francisco, United States: Jossey-Bass Publications, 1988.

[32] F. Sepulveda, "El Modelo competing values framework (CVF) y el diagnóstico de la cultura organizacional [Compeling Values Framework Model (CVF) and the organizational culture diagnostic]," Economía y Administracion, vol. 63, pp. 7-27, December 2004

[33] D. J. Hellriegel, W. Slocum and R. W. Woodman, Comportamiento Organizacional [Organizational Behavior], $8^{\text {th }}$ ed., México: Thomson Editores, 1999.

[34] J. Edwards, M. Collier and D. Shaw, Knowledge Management and its impact on the Management Accountant. London, England: Aston Business School, Aston University, 2005.

[35] I. Nonaka, "A dynamic theory of knowledge creation," Organizational Science, vol. 5, pp. 14-37, 1994. http://dx.doi.org/10.1287/orsc.5.1.14

[36] A. Mihi, "Un análisis de la gestión de la calidad total y de la gestión del cocimiento como fuente de ventajas competitivas [An analysis of the total quality management, and the knowledge management as a source of competitive advantages]" Revista Universidad \& Empresa, vol. 7, pp. 163-177, 2008.

[37] I. Nonaka, and D. Teece, Managing industrial knowledge: creation, transfer and utilization. London, England: SAGE Publications, 2001.

[38] C. Bratianu, “A critical analysis of Nonaka's model of knowledge dynamics," Electronic Journal of Knowledge Management, vol. 8, pp. 193-200, 2010.

[39] I. Nonaka and R. Toyama, "The knowledge-creating theory revisited: knowledge creating as a synthesizing process," Knowledge Management Research \& Practice, vol. 1, pp. 2-10, 2003. Retrieved from http://www.palgrave-journals.com/kmrp/ index.html, http://dx.doi.org/10.1057/palgrave.kmrp.8500001
[40] I. Nonaka and G. Krogh, "Tacit knowledge and knowledge conversion: controversy and advancement in organizational knowledge creation theory," Organizational Science, vol. 20, pp. 635-652, 2009. http://dx.doi.org/10.1287/orsc.1080.0412

[41] R. Hernández, C. Fernández-Collado and P. Baptista, Metodología de la Investigación [Research methodology], $6^{\text {th }}$ ed., México: McGraw Hill, 2014.

[42] A. Mihi, V. J. García and R. M. Rojas, "Knowledge creation, organization learning and their effects on organizational performance," Inzinerine Ekonimika-Engineering Economics, vol. 3, pp. 309-318, 2011.

[43] F. Hair, R. Anderson and W. Black, Análisis multivariante [Multivariate analysis], $5^{\text {th }}$ ed. España: Prentince Hall, 2004.

[44] D. Anderson, D. Sweeney and T. Williams, Estadística para negocios y economía [Statistics for businesses and economy ], $11^{\text {th }}$ ed., México: Cengage Learning, 2011.

[45] J. Cohen and P. Cohen, Applied Multiple Regression. Correlation Analysis for the Behavioral Sciences, $2^{\text {nd }}$ ed. New Jersey, United States: Erlbaum Publications, 1983.

[46] J. M. Wooldridge, Introducción a la econometría [Introduction to econometrics]. México: Thompson, 2000.

[47] R. Casas, "Between traditions and modernity technological strategies in three tequila firms," Technology in Society, vol. 28, pp. 407-419, 2006. http://dx.doi.org/10.1016/j.techsoc. 2006.06.007

[48] Consejo Regulador del Tequila, Estadísticas [Statistics]. Enero, 2013. Retrieved from www.crt.org.mx

\section{AUTHORS}

Marco Alberto Núñez Ramírez is with the Department of Management, Instituto Tecnológico de Sonora, Ciudad Obregón, Sonora, México (e-mail: marco.nunez@itson.edu.mx).

Teodoro Rafael Wendlandt Amezaga (corresponding author) is with the Department of Management, Instituto Tecnológico de Sonora, Calle 5 de febrero 818 Sur, C.P. 85000, Ciudad Obregón, Sonora, México (e-mail: teodoro.wendlandt@itson.edu.mx).

María Trinidad Álvarez Medina is with the Department of Accounting and Finance, Instituto Tecnológico de Sonora, Ciudad Obregón, Sonora, México (e-mail: talvarez@itson.edu.mx).

This work was supported in part by Instituto Tecnológico de Sonora trough the "Program for the Support and Development of Research Projects" (PROFAPI, by its Spanish acronym). Submitted, 06 April 2016. Published as resubmitted by the authors 19 April 2016. 